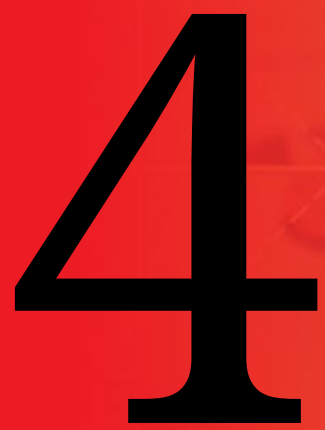

THE LANGUAGE OF DISCIPLINE

\title{
Gloria Davies
}

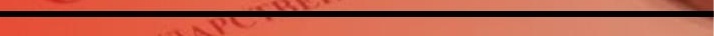


'Party discipline' is shorthand for enforcing the Party's internal rules and regulations and eliminating corruption and other types of wrongdoing. In 2016, Party discipline came to play a major role in Xi's efforts to secure his control over the CCP and all its members. At several provincial-level Party meetings in early-tomid-January 2016, local leaders further pledged 'to resolutely safeguard General Secretary Xi Jinping as the core' 坚决维护 习近平总书记这个核心 - implicitly identifying Xi's personal authority with Party discipline. These local leaders also cited a

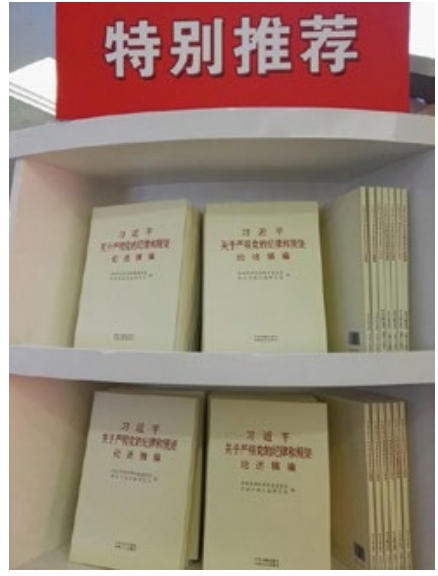

'Special Promotion': Xi jinping's Edited Excerpts on Discipline

Image: ccdi.gov.cn new and complementary slogan - 'Four Types of Consciousness'四种意识: Party officials are to strengthen their 'political consciousness, consciousness of the big picture, consciousness of the core, and consciousness of the need to keep in line' 增强政治意识、 大局意识、核心意识、看齐意识. ${ }^{1}$ These new expressions surfaced from time to time in the state media and on Party websites. Then, in October, their authority as new official formulations, tifa 提法, became clear. (For more on tifa, see the China Story Yearbook 2014: Shared Destiny, Chapter 4 'Destiny's Mixed Metaphors', p.150.)

At the Sixth Plenum of the CCP's Eighteenth Central Committee, held from 24-27 October 2016, the Party leadership confirmed 'Xi Jinping as the core' and the 'four types of consciousness' as key features of Party governance. The focus of the three-day meeting was the question of how to achieve 'comprehensive and strict Party governance' 全面从严治党. This phrase appeared no less than fifteen times in the communiqué issued at the end of the meeting, which was also published as an editorial in the People's Daily. The phrase is synonymous with 'strict enforcement of 
Party discipline'. The Sixth Plenum's declaration that 'The Party's Central Committee takes Comrade Xi Jinping as its core' meant that the content of Party discipline would henceforth be determined by what Xi had to say, or had previously said, on the subject. ${ }^{2}$

In fact, by then Party members were already engaged in mandatory, systematic study of Xi's views on Party discipline. On 1 January 2016, China's state media and Party websites launched an online publicity blitz to promote the book Edited Excerpts from Discussions by Xi Jinping on Tightening Party Discipline and Rules 习近平关于严明党的纪律和规 矩论述摘编 (hereafter Edited Excerpts on Discipline). Published by the Party's Central Documents Press, it appeared without fanfare in mainland bookstores about two weeks earlier. ${ }^{3}$ It comprised no less than 200 extracts from over forty of Xi's speeches and essays from the period 16 November 2012 - 29 October 2015.

\section{Xi Jinping on Party Discipline}

To use Xi's favourite adjective, the book provided 'comprehensive' 全面 coverage of his views on Party discipline. He has spoken to different audiences about different aspects of discipline. On one occasion in 2014, for example, he urged his audience of county-level leaders to 'strengthen their capacity for self-inspection and self-purification' 必须加强自我监督、自 我净化能力. They were to also 'increase their efforts in supervising institutional operations at all levels'在体制机制层面加大监督力度. On

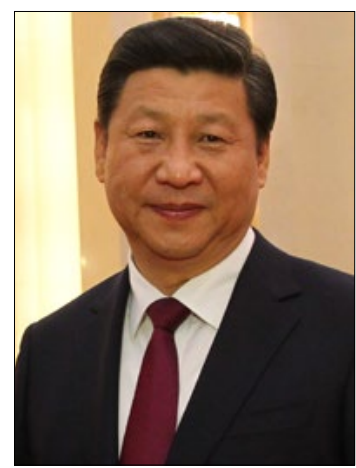

Xi jinping: Party whip Image: Wikimedia Commons 13 January 2015, he told the Party's Central Commission for Discipline Inspection (CCDI) that 'deepening the work of discipline inspection' was crucial for 'strengthening the Party's capacity 
RECKLESS AND AUDACIOUS, by Gloria Davies

Zhou Yongkang 周永康 had previously headed China's formidable state security system. Bo Xilai 薄熙来 was the former party secretary of China's most populous city, Chongqing. Xu Caihou 徐才 厚 had been a general in the People's Liberation Army. Ling Jihua 令计划, the former head of the United Front Work Department, was a key advisor to Xi's predecessor, former party general secretary Hu Jintao 胡锦涛. And Su Rong 苏荣 had served as deputy head of the Chinese People's Political Consultative Conference. These men were among the first 'tigers' to be arrested for corruption from 2012 to 2014. In early 2013, while still president-in-waiting, Xi vowed to crack down on both 'tigers' and 'flies'. 'Flies' denoted lowly bureaucrats. 'Tigers' referred to officials in senior positions, ranked at the deputy provincial level, deputy ministry level, or higher. In Xi's January

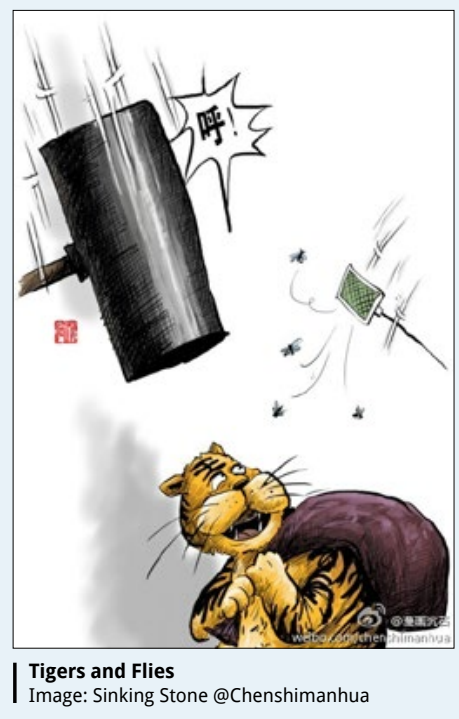
2015 speech, he described these particular 'tigers' as having flouted 'party discipline and political rules, to the point of recklessness and audaciousness!'

for institutional innovation' 加强制度创新. Speaking to a Collective Study Session of the Politburo on 26 June 2015, he spoke of the urgency of 'strengthening the development of anti-corruption laws and regulations' 加强反腐倡廉法规制度建设. And at the 119th Conference of the Eighth Central Committee Politburo Standing Committee on 8 October 2015, he stated that accurate identification of the main problems standing in the way of stronger Party discipline was an important priority.

Edited Excerpts on Discipline was the first general publication of these 'internal speeches' 内部讲话. ${ }^{4}$ One extract from Xi's speech at the CCDI meeting on 13 January 2015 attracted international media interest. In it, Xi described the enormous damage that Zhou Yongkang 周永康, Bo Xilai 薄熙来, Xu Caihou 徐才厚, Ling Jihua 令计划, and Su Rong 苏㭉 had caused the Party, labelling them as reckless and audacious. (See box above.) 
In an article for The New York Times, the Beijing-based journalist Didi Kirsten Tatlow called the publication of the extract tantamount to:

The first public and official declaration by President Xi Jinping of "political plot activities' by senior Communist Party officials 'to wreck and split the party' - code words for a coup attempt, several Chinese analysts said. Its release was a signal, they said, that the challenge was over, that the party had agreed on what happened and that Mr. Xi wanted people to know that he had overcome his adversaries. ${ }^{5}$

The timing of the official release of Edited Excerpts on Discipline on New Year's Day signalled that 'comprehensive and strict Party governance' would be the guiding topic of the Party's 'political thought work' in 2016. As of 5 December 2016, the book remains at the top of the official list of recommended works on Party theory - a list dominated by works written by Xi Jinping. ${ }^{6}$

More than any Chinese leader since Mao Zedong, Xi has sought to shape official discourse around his own pronouncements. The 2016 book on Party discipline is just one of fourteen anthologies of quotations and speeches by him that have appeared since 2013. As the new exemplars of correct Party diction and prosody, Xi's 'sayings' feature prominently in different types of official discourse: in the speeches of other Party leaders, party policies, government work reports, and compulsory political studies curriculum at universities, as well as articles and editorials published in the state-run media. To quote Xi correctly constitutes, after all, a display of discipline in the form of rhetorical accord with 'comprehensive and strict Party governance'.

At the heart of any discipline is a set of instructions. On an individual level, to discipline one's mind or body is to subject oneself to a prescribed set of mental or physical exercises, or trials, to achieve a desired goal. Whatever the goal, whether an improved attitude to life, greater under- 
standing of an area of knowledge, improved skills in an art or sport, or simply a better-looking body, the discipline must promise results for one to want to be subjected to it. The disciplinary measures of large organisations have a different purpose. Rules of conduct and punishments for transgressors predominate, for what matters is the wellbeing of the organisation. The individuals who belong to or work for it must accommodate their own needs and interests to the greater good. To go against the rules is to risk expulsion or worse. As Xi remarked to senior Party officials in Lankao county in May 2014:

As we are such a big political party, what can we rely on to govern our troops? What can we count on to overcome risks and challenges? The answer is, in addition to adopting the correct theory and the correct line, principles and policies, we must also rely on strictly following regulations and exercising strict discipline. We make so many demands. We want a multi-pronged approach to solve both the symptoms and the root cause of our problems. Relying on a full understanding of the situation is not enough. We must have strict constraints that can be forcefully implemented. This is what discipline means. ${ }^{7}$

\section{Marketing Discipline}

When addressing Party members and state officials, $\mathrm{Xi}$ is candid yet didactic. He combines forthright speech with formulaic language - for instance, the word-order for the phrase 'the correct line, principles and policies' is unalterable. China's official discourse reflects the authoritarian nature of its one-party system. Rigid formulations and verbose descriptions abound because Party leaders and theorists believe that the preservation of the 'correct' forms of words reflect a clear sense of order and disciplined unity - and this includes the laboriously long titles of official meetings such as 'The 119th Conference of the Eighth Central Committee Political Bureau Standing Committee'. 


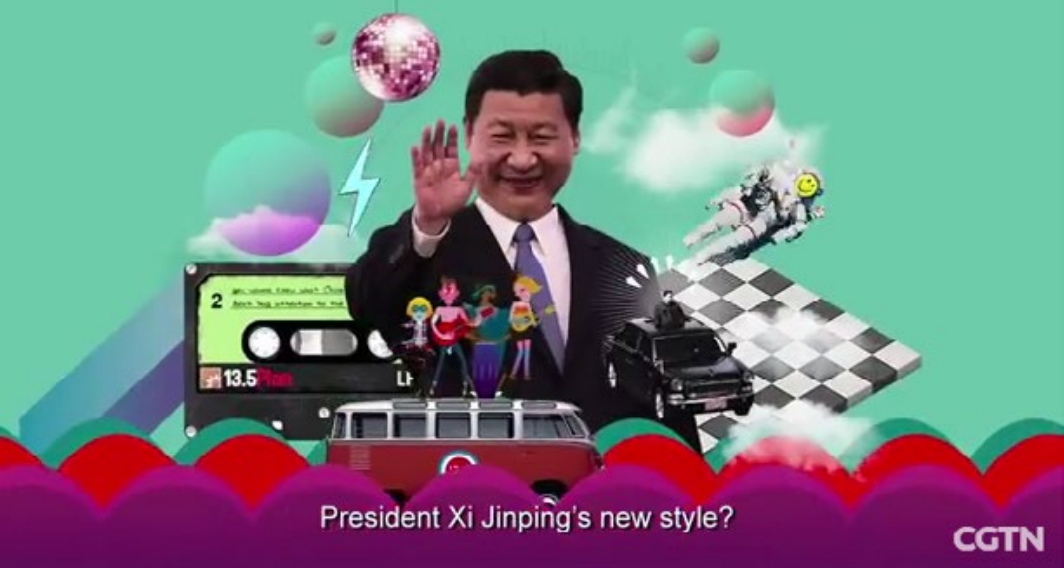

The animated English-language video explaining China's Thirteenth Five-Year Plan Source: YouTube

The language of the top leader influences official discourse. When Xi's ineloquent predecessor $\mathrm{Hu}$ Jintao was in office, people used the slogan 'Speak like a real human' to mock the kind of contrived and wooden official discourse that he represented. (See China Story Yearbook 2013: Civilising China, Chapter 7 'Fitting Words', pp.380-407.) Nonetheless, Hu's final year as Party Secretary in 2012 saw China's state media begin to experiment with an upbeat and colloquial tone. On 22 July 2012, when Beijing's heaviest rainstorm in sixty years led to massive flooding and the deaths of thirty-seven people, the People's Daily launched its Weibo account with the message:

No one's getting any sleep tonight while the storm engulfs Beijing. The official Weibo account of the People's Daily is keeping a vigil with everyone. We're saying a prayer for every person who hasn't yet reached home safely. We pay tribute to every person who is on the frontline of the battle to save lives! Go Beijing! ${ }^{8}$

This warm and friendly tone has become far more prominent in the Party's 'external discourse“ 外部讲话 under Xi and presents a striking contrast to the austere language used in 'internal' Party speeches. Cartoons and music videos are now frequently used to promote Party and state policies not only to the mainland public but globally. In 2015, China's Thirteenth Five-Year Plan was publicised, among other things, via an animated English-language music video with Chinese subtitles. (See Chapter 1 'What's the Plan?', pp.xxvi-15, and the China Story Yearbook 2015: 
Pollution, Forum 'The Road to Rejuvenation: The Animated Xi Jinping', pp.5-8.) When interviewed, official spokespersons praised the video but denied that the government had played any part in its production.

Then, on 2 February, Xinhua launched an animated Chinese-language music video about the 'Four Comprehensives'四个全面战略布局 on its online video website. A fortnight later, on 20 February, it re-released the video dubbed and subtitled into eight other languages (English, French, Spanish, Russian, Arabic, German, Korean, and Japanese) on various domestic and foreign social media platforms, including Facebook. But while official spokespersons had denied any government involvement in the Thirteenth Five-Year Plan video, in this case the government publicised its involvement from the outset.

\section{THE 'FOUR COMPREHENSIVES', by Gloria Davies}

$X i$ first used the 'Four Comprehensives' 四个全面战略布 局 in mid-December 2014. The term became an official slogan two months later. It stands for: comprehensively building a 'moderately prosperous 小 康 society, deepening reform, governing the nation in accordance with law, and strictly governing the CCP'. The first three tasks are continuations

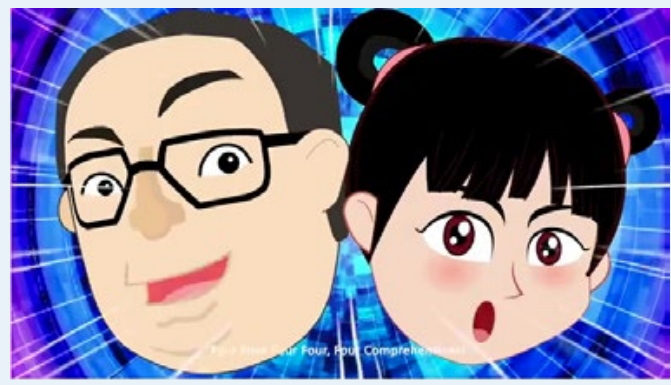

Still from the 'Four Comprehensives' video Source: YouTube of post-Maoist national goals promoted by previous administrations. The fourth is Xi's defining initiative.

Party slogans appear to be fixed, eternal formulations even though they are, in fact, improvisational and contingent in nature. Throughout the first eleven months of 2014, Xi had spoken only of 'Three Comprehensives' (the first three). As Chris Buckley pointed out in a New York Times article of 1 March 2015, it was only in November 2014 that Xi and his advisers 'decided that leaving out fighting corruption might send the wrong message', ${ }^{9}$ hence the addition of a 'fourth comprehensive' in his speeches in mid-December 2014. Party propagandists leapt to the task of providing justification for the sudden change. Buckley quotes one official commentator as praising the 'profound implications' of this 'even more complete and even more mature overall framework for governance and wise rule'. 
'DIVINE TUNE' 神曲, by Gloria Davies

The term means a 'viral hit' - a catchy song that 'mesmerises' or, literally, brainwashes 洗脑 and sticks in people's heads for some inexplicable 'divine' reason. It is also the standard Chinese translation for Dante Alighieri's epic poem The Divine Comedy.

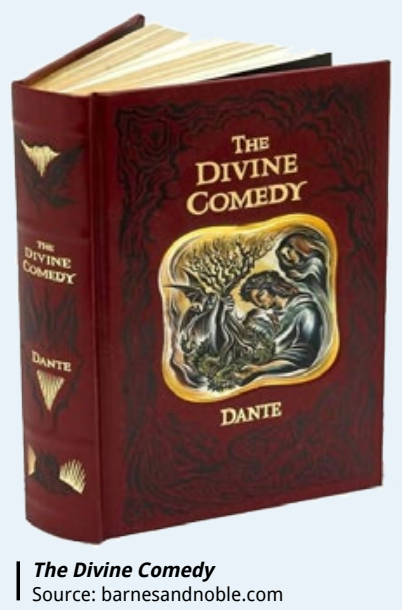

The video opens with a rhyme inspired by geometry 一个那是点, 两个那是线, 三个那是面, 四个是全面. The official English translation is 'One is just a point, Two can form a line, Three become a plane, Four will do all fine!' More literally, the last line means 'four's what makes them comprehensive'. This implies that the 'fourth comprehensive' ('strict Party governance') is key to integrating the first three. The three-minute video quotes the 'Four Comprehensives' and several of Xi's other catchphrases. Xinhua's Weibo account invited viewers to post comments. On 3 February, Xinhua published an article explaining the visually busy video's different elements and cited some of the more enthusiastic responses it had received. ${ }^{10}$

The same day, Hong Kong-based Radio Free Asia reported that, in fact, the video had attracted more negative than positive responses and that Xinhua's original proclamation 'It's here! Xinhua Agency's "Divine Tune”!' 来了! 新华社“神曲”! had inspired noticeable ridicule. ${ }^{11}$ One netizen called it 'new generation "Divine Tune" brainwashing'. Another suggested that Xinhua used the word 'divine' because the subtext was redolent of the Maoist chant: 'ten thousand years, ten thousand years, a hundred million years to the ruler!' 皇上万岁万万岁. Yet another marvelled at the persistent obsession of China's top Party leaders with theorising by numbers, listing just a few predecessors to Xi's 'Four Comprehensives': Mao's 'Ten 
Major Relationships’十大关系; Deng Xiaoping's 'Four Cardinal

Principles' 四项基本原则, Jiang Zemin's 'Three Represents' 三 个代表, and Hu Jintao's 'Eight Honours and Eight Disgraces' 八 个为荣、八个为耻. Xinhua published a number of mildly mocking posts about the video on its Weibo account.

Less than three weeks after the launch of Xinhua's 'Divine Tune', on 19 February, Xi deliv-

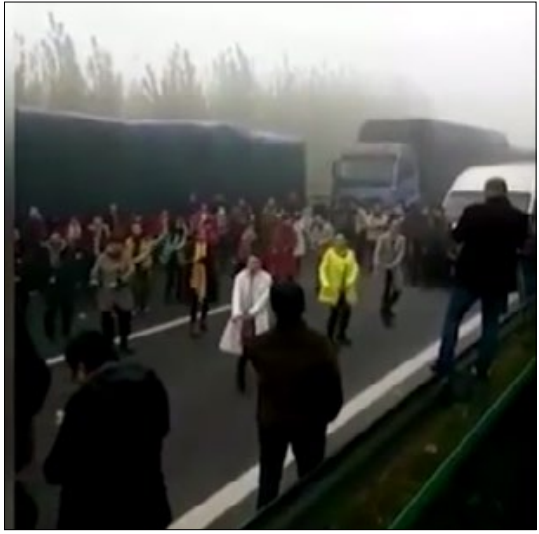

Dancing women during a traffic jam in north China Source: Weibo

ered a speech at the Party's News and Public Opinion Work Conference in Beijing, in which he stressed the importance of Party and state media 'cleaving fundamentally to the Party's leadership' so that they can serve as 'propaganda battlefronts of the Party and the government' 党和政府的宣 传阵地. He quipped that the media 'must bear the Party's surname' 必须姓 党 in every aspect of their work. ${ }^{12}$

The Thirteenth Five-Year Plan and Four Comprehensives videos clearly set out to satisfy all of Xi's criteria as described in that speech: they sought to 'embody the will of the Party'; 'mirror the views of the Party'; 'preserve the authority of the Party, preserve the unity of the Party, and achieve love of the Party, protection of the Party and act for the Party'. ${ }^{13}$

Media reports describe the musical style of the two videos as 'rap' shuochang 说唱; as spoken word set to generic pop tunes, they are more akin to commercial jingles. ${ }^{14}$ This form of ideological marketing draws some attention, in and outside China, to the Party-state's medium, if not its message. Xinhua claimed on 20 February that 'the Chinese version [of the 'Four Comprehensives' video] went viral both home and abroad, with The New York Times, CNN, The Guardian, among many news providers across the world posting the video'. ${ }^{15}$ In reality, international media outlets simply published articles reporting that the Chinese Party-state was making animated musical cartoons to convey its propagandistic messages. 
Neither has gone viral in the manner of, say, the January 2016 video of a 'Mr Li' from Changchun playing guitar while undergoing brain surgery or that of women dancing on the highway during an hour-long traffic jam in north China in November 2016. This points at the very least to general indifference to the ideas and slogans being promoted. Party propagandists have yet to work out how to get most Party members - let alone average citizens - excited about such exemplars of 'Party thinking' as the Four Comprehensives.

\section{The 'Spirit of the Craftsman'}

Slogans promoting cultural and economic development such as Premier Li Keqiang's 'Spirit of the Craftsman' 工匠精神, which encourages innovation, gain more traction in the popular sphere but they receive nothing close to the publicity given to Xi's pronouncements on Party building and discipline. Li first used the expression Spirit of the Craftsman in an address to the National People's Congress in Beijing on 5 March 2016. After outlining the challenges presented by slowing economic growth, Li spoke of the government's commitment to innovation-driven economic development. In order for Chinese-made goods to become globally competitive, he encouraged enterprises to adopt 'flexible and customtailored production processes and foster the spirit of the craftsman, of striving for the best, so that more types of products, products of a higher quality, and [recognisable] brand products will be made'. ${ }^{16}$

Li returned to the topic on 29 March 2016 at a speech at the China Quality Award Presentations ceremony in Beijing. He urged people working in China's goods and services sector to aspire to international standards of excellence, exemplified by 'English tailored suits, Royal Dutch Companies, Germany's vocational education and Japan's millennium-old sword-smithing art'. The saying struck a chord with academics and media commentators, who offered their thoughts on the type of self-discipline required to cultivate the Spirit of the Craftsman. ${ }^{17}$

$\mathrm{Xu}$ Jilin 许纪霖, the eminent Shanghai-based historian and public intellectual, presented a lecture on the Spirit of the Craftsman in Shenzhen on 


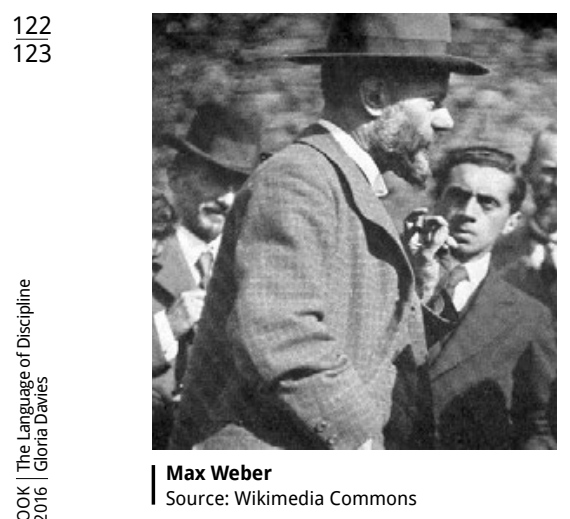

18 June $2016 .{ }^{18} \mathrm{Xu}$ pointed out that craftsmanship required not only professional excellence but an ethical attitude as well. It implied devoting oneself to one's art, craft or profession in a disciplined manner for the sake of excelling at it, not just because it might lead to financial profit.

To illustrate, Xu quoted Max Weber's views on the ideal or genuine 'politician'. In 'Politics as a Vocation', Weber had argued that 'three pre-eminent qualities are decisive for the politician: passion, a feeling of responsibility, and a sense of proportion'. ${ }^{19} \mathrm{Xu}$ said that craftsmanship required: 'value rationality total commitment and dedication to the value objectives one has adopted', 'a real sense of mission and the sense of responsibility needed to realise one's mission' and 'the detached judgement that comes of seeing reality without being swayed by feelings, and the insight derived from thoroughgoing reasoning'.

Xu's verbose rewording of Weber's succinct statement is a typical example of oblique commentary in the highly censored realm of mainland intellectual discourse. Obliqueness indicates that there is more than meets the eye, that the author cannot speak freely. Xu presented his argument as academic, that is, non-political, by using specialist, discipline-based terms (such as 'value rationality' and 'value objectives') and by attributing the view being expressed to Weber rather than himself. That Xu did not explain why he chose to quote Weber on the qualities of a true politician (as opposed to on any other topic) is par for the course. Oblique commentary assumes that the sympathetic reader 'gets' what is being implied. The problem is that there is no chance to elaborate, and this is detrimental to intellectual inquiry in mainland China.

Weber had been the Western thinker of choice for most Chinese intellectuals in the mid- to late 1980s, in the heyday of the 'liberal' or 'New 
Enlightenment' thinking that preceded and, in many ways, inspired the student-led democracy movement at Tiananmen Square in 1989. After listing his three Weberian definitions of the Spirit of the Craftsman, Xu lamented the lack of this spirit among 'the large numbers of intellectuals today who have become experts, who do research and write books purely to make a living and who don't have the slightest personal interest in their area of expertise'. Conversely, a true craftsman 'pursues his profession as an amateur. He can't tell between work time and leisure time as he's simply doing what he enjoys.'

\section{Undisciplined Words}

Craftsmanship and discipline were spectacularly evident at the evening gala concert held on 4 September 2016 to mark the start of the Eleventh G20 Summit in Hangzhou. There were no less than ten full-dress rehearsals before the show. ${ }^{20}$ However, even as China's best dancers, musicians, and singers were entertaining

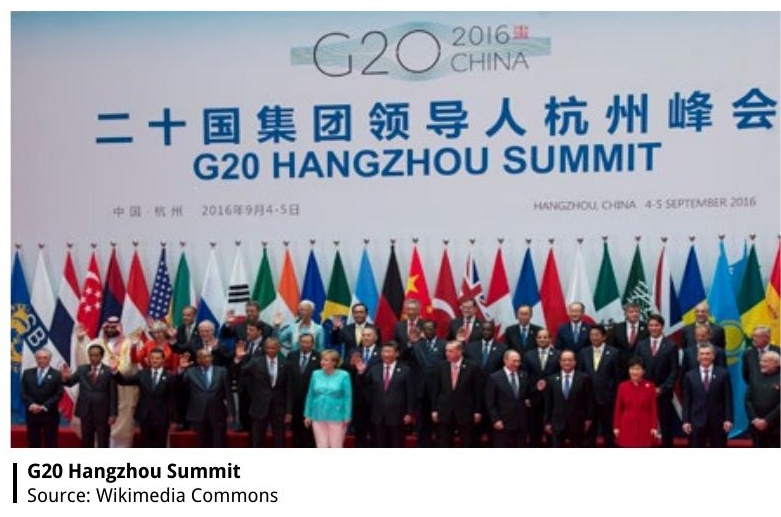
world leaders with their flawless performances, China's cyber-censors were busy deleting satirical comments about a gaffe made by Xi Jinping the previous day. In the course of delivering a speech to global business leaders, he quoted a line from the fourth-century BCE Chinese classic Discourses of the States 国语: 'Allow freer passage across borders and create safe roads, promote commerce, and ease the pressure on the peasants' 轻关易道, 通商宽农. However, what he said was: 'Allow freer passage across borders and create safe roads, promote commerce, and loosen ['ease'] your clothes' 宽衣. Whether the text from which he was 


\section{0 建设开放型世界经济 拓展发展空间}

Xi speaking at the G20 Hangzhou Summit

Source: CCTV

reading had used the wrong character, substituting 'clothing' 衣 yi for 'peasants'农 nong — the two characters look similar — or whether Xi had misread the character, remains a mystery. At any rate, he did not appear to notice he had misquoted the line.

As soon as Xi's speech was aired, cryptic comments began appearing on the mainland Chinese Internet about the necessity of 'disrobing' 宽衣 when 'doing business' 通商. On Twitter, which remains blocked in China, Chinese speakers openly made fun of Xi's blunder and cast doubts on his vaunted knowledge of classical Chinese.

The Beijing-based historian and public intellectual Zhang Lifan 章 立凡 composed a pair of eight-line heptasyllabic 'regulated verses' 律诗 (the character for 'regulated' 律 forms part of the modern Chinese word for 'discipline' 纪律) in critical commemoration of the G20 Summit. Outside China, the two poems circulated widely online. Zhang based one of the poems on the famous quatrain, 'At the Inn in Hangzhou' 題臨安邸 by the Song dynasty littérateur, Lin Sheng 林升 (1106-1170), celebrating the beauty of Hangzhou's West Lake. Zhang included a reference to Xi's gaffe in the last line of this poem (titled 'Two Stanzas on Flaying' 剥皮二首): ${ }^{21}$

Beyond the skies the stratosphere the mansion of mansions, When will the imperial household awaken from its springtime dream? The praise of the world's barbarian tribes intoxicates the brilliant sage-ruler,
天外云天楼上楼,

帝家春梦几时休?

四夷捧得明君醉, 
As if to rule the earth while

坐在杭州管地球。 seated in Hangzhou.

The arriving guests drove the 客来驱主人烟少， host to empty the town, The singing and dancing in the 歌舞空城景独奇. deserted city was truly spectacular. But just as ugly Dong Shi played 欲扮东施作西子, at being beautiful Xi Shi, The result was too much make-up 艳妆浓抹乱宽衣。 and dishevelled undress.

Zhang's poem reflects a disciplined ease in the use of literary and colloquial Chinese. Rich in quotidian references, literary allusions, and fragments of quotations familiar to educated Chinese, it embodies the Spirit of the Craftsman. The 'mansion of mansions' 楼上楼 in the first line is a popular name for Chinese restaurants in China and abroad, including a famous one by Hangzhou's West Lake. The 'deserted city' in the original alludes to a ruse employed by the famous military strategist Zhuge Liang 诸 葛亮 (181-234 BCE). Zhang used the phrase 'deserted city' to highlight the state's closure of large sectors of Hangzhou, greatly inconveniencing the city's residents, more than one-third of whom were made to leave town during the week of the summit. 


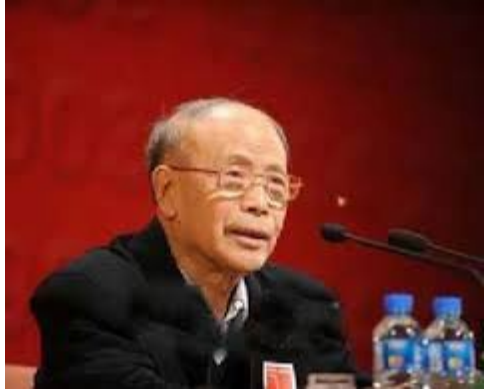

Du Daozheng

Source: Baike
The expression 'to rule the earth' 管地球 was used by Mao Zedong in 1955 to describe the mission of the new nation's leading news agency, Xinhua, which was to send correspondents overseas to spread the cCP's message abroad. The expression also featured in the title of a widely-read essay on the history of Xinhua's overseas bureaus, 'How

Xinhua sought to rule the earth' 新华社要把地球管起来 published in the July 2013 issue of the influential monthly Yanhuang Chunqiu 炎黄春秋.22

As discussed in 'Intellectual Hygiene/Mens Sana' in the China Story Yearbook 2015: Pollution, Yanhuang Chunqiu had previously enjoyed certain privileges because most of the people who worked on and contributed to the magazine were retired senior Party officials. These Party veterans sought to publish candid accounts of their experiences of the Party-state's workings, the turbulence of the Maoist period, and the Party leaders they had served. Under Xi's administration, they faced increased pressure to exercise self-censorship. The pressure intensified in 2016 when the magazine sought to publish reflections on the fiftieth anniversary of the launch of the Cultural Revolution in May.

In July, without warning or consultation, Yanhuang Chunqiu's supervisory body, the Chinese National Academy of Arts, dismissed the magazine's publisher Du Daozheng 杜导正 and replaced the entire editorial committee with its own appointees. Senior Academy officials deployed staff to occupy the magazine's premises and changed the operational password for the magazine's website. The new administrators clearly intended to capitalise on the magazine's enviable reputation, while turning it into a 'comprehensively and strictly Party governed' vehicle. In response, on 18 July 2016, Du announced that Yanhuang Chunqiu was no more: 'From now on, anyone who publishes in the name of Yanhuang Chunqiu [is] unrelated to this journal'. ${ }^{23}$ 
ZHANG LIFAN'S 'TWO STANZAS ON THE PROSPEROUS AGE', translated by Gloria Davies

Gaudy and extravagant, a glittering appearance,

A splendid banquet keeps Chinese and barbarian taste buds busy.

Grass-like commoners exert themselves, their blood and toil,

Becoming the detritus that forms a palace ditch.

When will we stop seeing clones everywhere?

The same tired martial arts routines lack artistry*.

With half a basinful of West Lake's feet-washing water,

Official Zhang, his talent spent, arrives in Hangzhou.
艳俗穷奢表面光,

华夷盛宴舌尖忙.

草民亳血洪荒力,

化为御沟一段翔.

克隆印象几时休?

套路湖乏艺谋.

西子半盆洗脚水,

张郎才尽到杭州.

\footnotetext{
* wu yimou - a play on Zhang Yimou's name. 'Feet-washing water' refers to the outdoor concert stage on which the performances took place. To create an impression of performers dancing and walking on water, the stage, completed in 2007, was built three centimetres below the water surface.
}

Zhang Lifan, who had previously contributed numerous essays to the magazine, remarked that the magazine had sought 'to save the Party, but the Party doesn't want to be helped'. ${ }^{24}$ Zhang's dismay at the magazine's demise was undoubtedly also behind the barbed wit he displayed in his two G20 Summit poems. (The other poem mocks the evening gala concert on West Lake and the concert’s director Zhang Yimou 张艺谋.)

\section{Conflicting Vernaculars}

Under Xi, intellectual life in mainland China has eroded dramatically. By 2015, there were arguably only two influential and popular outlets for independent debate. Yanhuang Chunqiu was one. On 1 October, National Day, the founder of the other, the Consensus website, 共识网, Zhou Zhixing 周志兴, posted this announcement on WeChat: 'Notice is given herewith that the authorities want us to shut Consensus down. They see it as a platform that disseminates the wrong type of ideas. We have no choice but to comply' 当局希望我们关闭共识网, 认为是传递错误思想的平台. 我们无 奈准备关闭. 特此报告. 25

Before the elevation of Xi Jinping to 'the core' of the Politburo and Party in 2016, Yanhuang Chunqiu and Consensus had survived thanks to extensive connections with and experience in elite Party circles. Back in 1987 Zhou Zhixing had even established the Party's Central Documents 


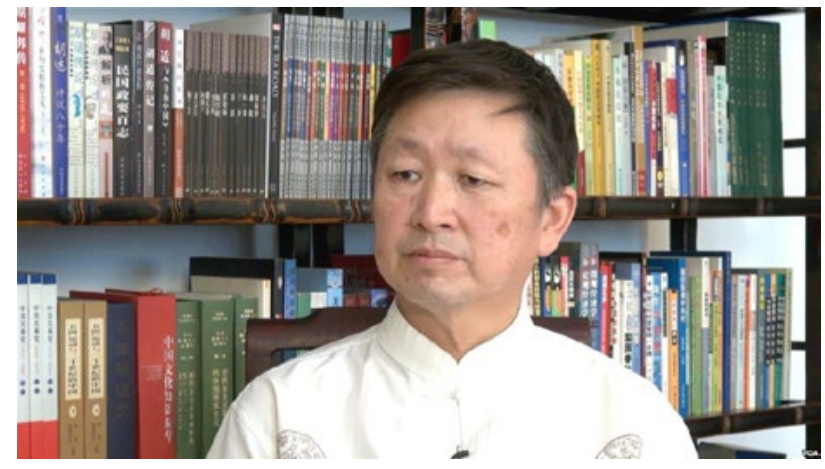

Zhang Lifan

Source: Wikimedia Commons

Press that published Xi Jinping's Edited Excerpts on Discipline in 2016 under instruction from the Party's Central Committee. Zhou served as the Press's vice-president until 1996.

On the Chinese-language Internet outside China, the closure of these two publications in 2016 elicited scathing criticisms of Xi's comprehensive and strict Party governance. At a roundtable discussion organised by the Voice of America's Chinese Branch in Washington DC on 7 October, Gao Wenqian 高文谦, a senior policy advisor at the New York-based NGO Human Rights in China, remarked that with the demise of Yanhuang chunqiu and Consensus, 'China has entered an age in which people's mouths are comprehensively sealed. This is the mark that the Xi Jinping era will leave on history.' Yang Jianli 杨建利, president of the Washington-based NGO Initiatives for China, commented that “ "Obey the rules” is the type of language secret societies use. To discipline Party cadres using this language shows that the CCP conducts itself like a secret society ... However, Xi Jinping's word isn't law in the way that Mao Zedong's and Deng Xiaoping's were, which is why he keeps resorting to Party rectification and shock and awe tactics in his bid to gain absolute control.' Cheng Xiaonong 程晓农, chief editor of the Princeton University-based Chinese-language journal Modern China Studies 当代中国研究, observed that Xi's efforts at strength- 
ening Party discipline by getting 'the people lower down to closely follow those higher up', would at best be limited to controlling high-ranking officials at the provincial or ministerial level. He would have enormous difficulty controlling the Party base because of the hidden rules 潜规则 of patron-client relationships (between officials of different ranks) that have defined the post-Maoist bureaucracy for more than two decades. Moreover, 'while it's easy to spout rhetoric about "closely following [the higher ups]", it's highly unlikely that the temptation to be corrupt among officials will be eradicated'. ${ }^{26}$

That Xi and his fellow Politburo members have chosen to push Party discipline in 2016 indicates both an extreme resistance to political reform and an abject reliance on control. When the modern Chinese written vernacular, baihuawen 白话文, was first promoted in the 1910s, it was extolled as a vehicle for free speech and egalitarian communication. Yet from the outset there was also a desire to 'guide and instruct' 引导 among many of baihuawen's advocates. The CCP's language, which developed out of this incipient vernacular from the 1920s onwards, turned baihuawen into an instrument of propaganda and control. However, to imagine that people can be permanently disciplined into using prescribed formulations is a totalitarian folly. This is all the more evident when we compare the Party's disciplined language, which abounds with such statements as 'By his actions in this great new struggle, General Secretary Xi Jinping has already become the core of the Party's Central Committee and the core of the whole Party ${ }^{27}$ with the expressive diversity of China's netizens, $\mathrm{Xu}$ Jilin's oblique commentary, Zhang Lifan's satirical 'regulated verse', and the unfettered eloquence of Chinese commentators overseas. 
This text is taken from China Story Yearbook 2016: Control, edited by Jane Golley, Linda Jaivin and Luigi Tomba, published 2017 by ANU Press, The Australian National University, Canberra, Australia. 